\title{
Constructing National and Local Identity in the Third World: New Museology Movement and Its Challenges
}

\author{
Peinan Cheng ${ }^{1, \mathrm{a},{ }^{*}, \dagger}$, Wenxuan Zhang ${ }^{2, \mathrm{~b},{ }^{*}, \dagger}$, Yanning Huang ${ }^{3, \mathrm{c},},{ }^{*}, \dagger$ \\ ${ }^{1}$ Shandong Jianzhu University, Jinan, Shandong, China. \\ ${ }^{2}$ Northwest Minzu University, Lanzhou, Gansu, China. \\ ${ }^{3}$ Tongji University, Shanghai, China.

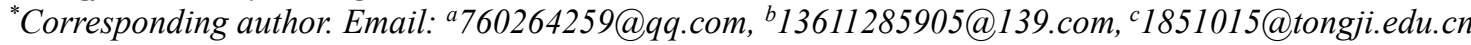 \\ These authors contributed equally.
}

\begin{abstract}
The essay explores how to use the New Museology theory to eliminate the dominant position of Eurocentric historical view in the third world and how to use eco-museum and community museum to build the national identity and local identity of the local people. With the rise of the New Museology Movement and the Cultural Heritage Protection Movement, the community museums and eco-museums established can reflect the current social evolution, and at the same time, can increase the recognition of people of different races to the cultures of different races. This phenomenon has been observed in the 21 st century, and there are not many scholars studying it. The essay will reveal that the New Museology theory can deconstruct the existence of Eurocentrism by establishing community museums to a certain extent. The essay uses the case study method and interview method. By studying the present situation of museums in some third world, this article hopes to have a wider reference significance for reshaping people's historical view in postcolonial areas. In conclusion, the essay deepens our understanding of New Museology, Community Museum, Ecomuseum, and the Third World. Admittedly, the essay is limited because the number of cases is small, which makes it impossible to make a more comprehensive analysis of this phenomenon. In addition, due to the differences of countries, there may still be many problems in our analysis methods. Further studies can look into the development of public archaeology and construct a more systematic New Museology theory.
\end{abstract}

Keywords: New Museology Movement, New Museology, Community Museum, Eco-Museum, the Third World, Eurocentrism.

\section{INTRODUCTION}

The essay's research question is to analyze to what extent can New Museology movement construct the national and local identity in the third world. As a part of the social revolution, the museum has been changing with every wave of thought, so this research question is puzzling. Moreover, the national museums have evolved to community museums and eco-museums, which made the realm of museology complex and unique.

To give background information, our research will firstly analyze the universal problem of postmodernism. After World War II, the economic boom and social development brought about serious social problems such as environmental pollution and the popularity of consumerism in capitalist countries. Although people in these countries own many materials, they still lack a sense of fulfillment and belonging, so people began to seek their roots. Additionally, in the 1960s, the civil rights movement in Western countries advocated the equal rights of marginalized people of the society, which also triggered the tendency of rewriting their history in the movement. According to Theodor Adorno's theory of identity and non-identity thinking, these marginalized people began to fight for their non-identity status. John Holloway suggested that non-identity can only be a force that changes itself, drives beyond itself, and recreates itself [1].

With the expansion of globalization, the third world countries which had been colonized before, such as India and China, had been profoundly influenced by the social revolutions in the Western World, resulting in changes in museology. Like France after the Revolution, they are 
attempting to regain their national identity through the national museums.

According to Mary Bouquet, the concept of nation has been materialized in the museum after the old regime's fall. Then the collections became an effective means to concrete the "we". Additionally, excavating, collecting, classifying other populations became means of objectifying the "other", thus reinforcing a sense of shared identity as members of the imagined community of the nation state [2].

However, it has been doubted whether the classic national museum can virtually shape the national identity of people of the former colonial countries. David Carrier suggested that the national museum cannot act as the ideal medium to help the natives to find their historical roots and gain a discourse power. He argued that because the expansionist project has peaked, the art museums must find new ways of making high art relevant to contemporary lives, or the masterpieces will be separated from their original context [3].

Therefore, people introduced the community museum as a result of the New Museology movement since the 1970s. Nevertheless, in some countries like China, the classic national museums had such a deep impact on the ideology of individuals that the community museums can hardly convey their thoughts to the public.

The methodological choices of our essay include literature collection, case study, and interview.

We interviewed the office of Shanghai Hongqiao Airport Community Museum about the project's content, purpose, and challenges. This case analyzes a comparatively successful attempt of a community museum, which was established by a social organization and contributes to local financial development.

To further analyze this problem, we also chose a certain case of the Art Museum of Chongming district of Shanghai as the comparatively unsuccessful example. This is a unique case because the Chongming Art Museum is one of the district museums of Shanghai, representing the history of art in this town. The case analyzed the basic purpose of some exhibitions of this museum and why it failed to attract local residents to visit it. This case applies to an appropriate instance of community museums, so it can virtually reveal the limitation of New Museology in a third-world country like China.

The theoretical study of the New Museology has always been lagging behind its practice and exploration. A systematic and complete theoretical system has not been established yet, resulting in many problems in the practice of the community museums. Our research is intended to utilize the relevant ideas of New Museology to reshape individual's conception of history in the postcolonial regions.
With the rapid development of archaeology, we also hope to build a bridge of communication and understanding among audiences, scholars, and government agencies by developing public archaeology.

In this way, when the public visits the community museums, they can change their self-judgment on the authenticity of certain things and regain the recognition and affirmation of the history on display.

The essay is divided into several sections. After the introduction, the essay will examine the basic question: the relationship between the New Museology movement and the social revolutions after World War II. Next, the essay will look at the basic theories of identity construction, including the principle and limitation of constructing the national identity and local identity. The essay will then offer an analysis of the New Museology movement in China and explain its challenges. Analysis of some specific examples in this realm will offer institutional, social, and historical reasons why the community museum failed to attract residents. The essay will subsequently review the direction of future academic research, including the theoretical development of New Museology and the practical implications. The conclusion will summarize the whole essay and put forward several limitations of this essay.

\section{EMPTY HEART: GLOBALIZATION, POST-MODERNISM, AND THE NEW MUSEOLOGY MOVEMENT}

French historian Tocqueville ever said, "When the past no longer shines on the future, people's hearts will wander blankly" [4].

In our industrial society, there are numerous onedimensional persons. They can only blindly follow and affirm, ignoring history intentionally or accidentally, so no one cares about the voice of the marginalized people, and no one cares about why our buildings are designed so ugly.

Thus, why is an industrial society lacking humanistic care? We will describe this problem from two aspects.

The first stage involves that the major capitalist countries enter a new era of economic boom and social development after World War II. At the same time, as the Third World became independent through national independence movements, the imperialist colonial system also was destroyed. However, the new era not only caused serious environmental pollution but also triggered the popularity of consumerism.

In other words, although people own an abundance of materials, they still lack a sense of fulfillment and belonging, so the root-seeking doctrine began to turn its perspective to questioning and reflecting on industrial society in the context of postmodernism [5]. 
In the following stage, for people living on the margins of society, the root-seeking doctrine has political and national significances. In the 1960s, the civil rights movement and the Cultural Heritage Protection Movement in Western developed countries became stronger, which means marginalized people were fighting for their equal rights. At the same time, the American archaeology community noticed that many precious historical resources were facing the threat of being completely destroyed. Thus, the emergence of "new archaeology" marked a new era in the development of archaeological theory. Archaeologist Lewis Binford pointed out: "Archaeologists should abandon the view of cultural history archaeology, that is, culture is a collection of typical material remains. Archaeologists should regard it as a way of human adaptation to the super-physical body of the environment." In other words, public archaeology came into being in the 1960s.

For example, the civil rights movement of minorities in the United States urged them to miss and seek after their history and rural culture. "They also began to seek their roots. At this time, people began to be interested in minority culture and heritage again, resulting in 'black music', books on the search for roots of people of color, and return of long-distance treasure exhibits... Through archaeological research and related literary works, the nation's history before colonization has been rediscovered" [4]. Since then, in all areas of society, marginalized classes have begun to challenge the mainstream central culture and demonstrate their right to speak.

However, whether it is people who question industrial civilization or people who fight for their rights, their actions have shown the important value of history and humanistic care. Coincidentally, the social movements inevitably impact the field of museology, so as a response and expansion of the social movements, a rural cultural concept that highlights history and marginalization began to take root and experiment in the New Museology Movement.

In other words, how to protect the particularity and difference from the standpoint of local society and marginal culture and achieve the purpose of the change was the fashion of the academic circles at that time [6]. Hence, people began introducing museology to a new museum practice that criticized modern culture and advocated marginal and local culture. Therefore, in the mid-1980s, a complete and systematic New Museology system based on the original concept of "community" and the existing eco-museums has emerged, that is, New Museology [7]. In the New Museum Movement, people build more marginal and rural eco-museums and community museums, which realized the preservation of the past culture and demonstrated its historical and practical value, thus promoting the self-development of local groups.
And under the influence of globalization, the Third World in the late 20th century received the concept of New Museology, so this provided a concrete, practical means for the Third World to try to find its own history and get rid of the influence of globalization Eurocentrism.

Therefore, these social revolutions had a profound impact on the realm of museology. Then the New Museology provides a mirror into globalization, postmodernism, and the New Museology Movement, meaning the third world countries began to discover their own history and construct their own identities along with globalization.

\section{WHO OWNS THE HISTORY?}

In this era, people have been confused about "Who Owns The History", which is equivalent to "rootseeking". This topic should be thought about, or the major capitalist countries will continuously act as the "silent referent", and the marginalized people will have no contribution to their own society. Thus the New Museology was born under the background of postmodernism. And then, under the influence of globalization, the Third World in the late 20th century received the concept of New Museology, so they hope to use this concept to find their own history and to get rid of the influence of Eurocentrism.

In our view, because the functions of museums changed and the background influenced, the social revolution, such as the French revolution, affected the museology, and it will continue forever. We can build the national identity and local identity of the people in the third world through the New Museology.

\subsection{Constructing National Identity}

Cultural colonization is a common problem in the third world, that is, the process of Western countries trying to impose their ideology on new nation-states. In this process, people in these regions, especially marginalized people, will lose their voice. Then why would it only appear in the third world? That is essential to mention colonial issues. The vast majority of the Third World countries used to be imperialistic colonies, semicolonies, or dependent States. After their political independence, they faced the historic task of eliminating the remnants of colonialism, developing national economies, and consolidating national independence. They are important forces for maintaining world peace.

But in fact, people gradually realized the important role of museums in the social and political fields after the French Revolution. In Mary Bouquet's book Museums: A Visual Anthropology, she summarizes the study of museums all over the world [2]. Museums use ideas and approaches both from within and outside of anthropology to further people's knowledge of and interest in museums. 
She also analyzed how the concept of nation has been materialized based on the theory of Benedict Anderson. If the nation state started as an abstract entity, theoretically belonging to the people after the old regime's fall, then the collections became an effective means to concrete the "we". Additionally, excavating, collecting, classifying other populations became means of objectifying the "other", thus reinforcing a sense of shared identity as members of the imagined community of the nation state. The ability to display collections made overseas in museums at home and the reproduction and circulation of images and information via printed media contributed to a sense of national identity in the nineteenth century.

However, from the perspective of historical development, it is believed that classical museums, such as the National Museum, still have certain limitations and cannot shape the identity of the people of the former colonial countries.

Relevant theories include Museum Skepticism. The classic museum cannot act as an ideal medium to help the natives to find their historical roots and gain a discourse power, according to David Carrier [3].

We value old art because we believe that it provides a record of the distant past. But the museum skeptic questions that belief and doubts the use and interpretation of cultural relics in all kinds of museums. Can old art survive its transfer to the museum? Additionally, if the museum serves political goals, the art's context will be changed. That is, the historical hangings change how art is seen. A work of art can have different meanings in its varied settings. Just like this, the emergence of the New Museology theory alleviates this doubt to some extent.

Carrier has such doubts about museums. He believes that since the inception of the public art museum during the French Revolution, it has experienced an expansion of collections, especially to include works representing non-European cultures. Especially, he emphasized the importance of narratives art museums offer the visitors. Therefore, under the influence of the New Museology theory, today's society should improve the detailed and objective interpretation of the exhibition collections in the museum to bring visitors immersive enjoyment.

\subsection{Constructing Local Identity}

The "Quebec Declaration" in 1984 marked the beginning of the New Museology movement, expanding the museum's function. It claimed that museums need to link history with the future, thus reflecting the evolution of society. For Subaltern Studies, it aims to uncover the histories of groups that within the colonial and nationalist archives went largely shunted to the margins or undocumented altogether. Therefore, the Subaltern Studies based on the postcolonialism theory gave some inspiration to the development of the New Museology movement and developed two new museum types: ecomuseum and community museum.

Nigel Rapport and others argue that "whether or not the community expresses a sense of belonging to the past, the commonality of current behaviour, political solidarity, or the future of a utopia (rural pastor of world order). The community is a concept of positive evaluation and appeal, and its application reflects a sociocultural group and environment that people expect, advocate and want to belong" [8]. So, we can find that the New Museology mainly focuses on "people" rather than "thing". The purpose of museums has also shifted from conveying specific knowledge to establishing historical, cultural, and local identity among the public.

Eco-museum and community museums can be synonymous with each other to a certain extent, but they are two different museum types in some respects.

First, eco-museum emphasizes the protection, preservation, and display of the authenticity, integrity, and originality of natural and cultural heritage and the living relationship between people and heritage. From the perspective of historicism, the essence of the ecomuseum movement is a concrete reflection on the disintegration of traditional nostalgia in capitalist industrialization [9]. From the perspective of the nationstate, the discovery and reaffirmation of local value by the eco-museum movement is a concentrated reflection of "decentralization" in the administrative system. In museum studies, the eco-museum movement represents a change mentality of participating in and serving society. From the comparative analysis of different museum types, the eco-museum movement focuses on the marginal places, cultures, and groups that are crushed by the process of modernity. Up to now, "eco-museum" is not only a relatively complete theoretical system and practical mode but also a kind of thought and concept.

Second, the community museum, which relies on the people-oriented concept, narrates the history of individuals and nations. Only through these personal memories and narratives can we understand what a highly politicized era means for individuals at a loss or even missing in the ideological wave. As survivors, how could they describe and reflect on their history? Relying on the cultural consciousness and self-management of the community residents to protect the local cultural heritage, the New Museology has constructed their cultural identity, realized the cultural autonomy of the community residents, promoted community development, and then resisted the "urban disease" brought about by today's society. From the rise to the peak and the division, the New Museology has experienced a few decades, and its practice in our historical district also has been going on for a few years.

Similarly, while using museums to construct local identity, we will also face many challenges. In China, 
most museums are built in relatively empty areas far from residential areas and school areas. Moreover, museums only advertise exhibitions through WeChat public accounts and museum official websites, so the form is very simple.

In general, eco-museum and community museums have certain limitations while constructing identity, and the development is not perfect. As a museum, they have poor mobility, unable to attract the audience to visit at any time. This will bring about a phenomenon that the publicity of museums is insufficient, resulting in the decreased enthusiasm of the audience.

\section{NEW MUSEOLOGY MOVEMENT IN CHINA AND ITS CHALLENGES}

This section is to analyze specific cases of community museums in China. To what extent can they construct residents' local identity?

China is the biggest developing country globally, representing the experience of the third world countries after World War II. And as a port city that Western countries had colonized, Shanghai possesses a unique but representative history of postcolonialism. Additionally, Shanghai has been emphasizing the development of new museums, especially community museums, since the $21 \mathrm{st}$ century.

The Art Museum of the Chongming district of Shanghai was opened to the public in 2012. By displaying local artists' works, accepting individual donations, and collecting residents' relics, it holds two types of exhibitions, including permanent exhibitions and temporary exhibitions.

The permanent exhibition displays the masterpieces of a local printmaker Huang Pimo, who profoundly influenced the history of Shanghai's art. Obviously, this exhibition was intended to inspire residents' sense of pride, thus fostering their local identity.

A representative temporary exhibition is an exhibition of carved boards collected from the natives. Disassembled from the mahogany bed, the carved board stands for the aesthetic appreciation of local people. Natives of Chongming are enabled to connect their past with their contemporary life through this exhibition. Specifically, they could realize the connection among each other because their boards are more or less the same, which means they are visible to one another, thus developing a sense of pride and identification among them. A shared history is one of the defining components of a community, representing the events that have bound them together [10].

However, the Art Museum of Chongming district failed to attract enough residents to visit it despite its various exhibitions. It represents the general problem of community museums in China, which can be explained in two ways.

\subsection{Institutional Explanation}

The Art Museum of Chongming district departments include Administration Department, Heritage Collection Sector, and Education Department. Obviously, the hierarchy established by the government is comparatively rigid and complex.

This is the first institutional explanation. The traditional management mode influenced new museums so much that the institutional hierarchy of community museums still followed the old mode. For example, the hierarchy of museums established by the government often includes a central hall, feature hall, and exhibition hall [11].

On the other hand, the finance and policy support from the government for the development of new museums are far from sufficient. The State Administration of Cultural Heritage had proclaimed a notification to promote the development of eco-museums and community museums in 2011 [12]. However, there have not been any laws or regulations to guarantee enough financial allocation yet.

\subsection{Social and Historical Explanation}

Apart from the institutional reasons, what cannot be ignored is the social explanation. The impression of museology on the public is often intangible and splendid. They would be reluctant to visit any kind of museum, although the community museum and eco-museum are different from the classic one. According to Mary Bouquet's perception of the classic museum, classifying other populations is a means of objectifying the "other" to reinforce a sense of shared identity as members of the imagined community of the nation state. This stereotype of the museum is derived from the traditional function of the national museum, namely narrating the history weighs heavily on the public and propagandizing some kind of ideology. This mode of identity construction had had such a deep influence on the public that they are not willing to construct another identity apart from the national identity.

This fact also leads to another social reason: the lack of community awareness and social participation consciousness. Group consciousness is defined as instances when a group maintains a sense of affinity and group identification with other group members, which leads to a collective orientation to become more politically active [13]. Correspondingly, community consciousness is based on the identification of community members with each other.

Specifically, in China, since there has always been a logical fault between the education of patriotism and 
community awareness, the community museum lacks communication to the public. The national identity is "enough" for the public, and they do not need to gain another community identity anymore. Therefore, the community museum is faced with the dilemma that it was initiated to foster community awareness, while the lack of such awareness, in turn, restricts its development.

\section{UTOPIAN ORIENTATION: THE FUTURE OF THE NEW MUSEOLOGY}

In short, the advanced ideas of New Museology challenged the "professionalism" of traditional museums, and most importantly, it has had a revolutionary impact on contemporary museology. Traditional museums are based on "objects", and their work revolves around collections. However, the community museum emphasizes the integration of museums and communities and emphasizes that "civilian culture" and "elite culture" are equal. At the same time, it also advocates that museums should actively participate in solving social problems and make their own contributions to community development. The museum is not a storage room but a mirror of social development and a platform for multicultural display and exchange of views.

We will describe this part from the perspectives of archaeology and sociology.

\subsection{Interdisciplinary Connection: The Community Museum is a Carrier of Community Archaeology}

As we all know, the museum is an important medium for the public to reconstruct history and participate in archaeology, but it also has the responsibility of educating the public. However, most of the traditional museums almost only serve the academic needs of archaeology, so they override the needs of the general public. These museums are like an "ivory tower": people inside cannot get out, nor can people outside get in.

For example, when the residents of Croydon in south London were asked what they wanted to see in a planned community museum, most people responded that they only wanted the memories of their ancestors. As a result, the local archaeological materials from the prehistoric period to the late medieval period have no place in this museum. In communities where these ethnic groups are very different, they are not interested in these ancient materials at all or think that these things have nothing to do with them [14]. So, can we combine community museums with community archaeology to solve this dilemma?

Archaeologists try to integrate into the community around the archaeological site, take the community members as the main body of public archaeological practice activities, and conduct public participation, dialogue, and exchanges on the premise of "partnership".
Based on this theory, public archaeology practice includes Community Archaeology, Marine Archaeology, and other activities. Hence, Community archaeology is an important part of public archaeology. Public archaeology attempts to incorporate different races or different social groups into archaeological activities, allowing them to discover and explain their own history. This practice of "community archaeology" has achieved good results in both the United States and Europe, especially in the cooperation between American archaeology and Indian tribes [15].

Therefore, we think that we can make community archaeology a specialized method to provide community museums with materials indirectly related to the history of community residents. Those materials seem to have nothing to do with each other but are inextricably linked in the development of the community because as early as the nineteenth century. It's a key factor in forming a state was the use of archaeological evidence to trace back in time the views of shared identities within the territory of the state.

In this way, the community residents can explain their own history, thereby deconstructing the ecological environment and cultural problems that appear in the post-industrial society because the common ground of community museums and community archaeology is "people-oriented".

\subsection{Innovation in Practice: To Present "the Cultural Process"}

It is generally believed that there is no fixed model for community museums. And community museums are a process of continuous exploration, and it is not the final result of New Museology. Moreover, the three characteristics of community museums, namely culture empowerment, sense of place, and sense of history, are trinity [14]. Thus, compared to the "static state" of traditional museums, community museums are a new kind of hope.

We will take the community museum established by a social organization, "DAYU community," in Shanghai Hongqiao Airport Xincun community, as an example. We interviewed Feng Bingbing, the person in charge of the community museum project, and he gave us a detailed account of the concept and current situation of the project. We learned from the conversation that they have obtained the support of the Shanghai Municipal Government, and they plan to set up a special foundation in the future to provide financial support for community charity projects.

They aim to go back to the community's development process, telling the story of the community members and exploring the shared history and feelings of the community. Finally, they can make the community 
members enjoy the previously lacking social resources by the personal participation of the residents.

DAYU first transforms cultural heritage into cultural resources and finally integrates cultural resources into a local cultural brand. This process reflects that the construction of community museums is a cultural process rather than a simple result [16].

The essence of people possessing history is that people have a right to interpret history. As declared by the "Six Knowledge Principle", an important norm of the International Eco-Museum, the community residents are the masters of culture. The museum's audience is no longer those elite groups who have been educated and share a common culture but everyone. At the same time, it also allows the museum to change its identity from an educator to a service provider, pursuing an audiencecentered concept [17]. However, in the construction process, initiators must also be wary of one thing: Will the construction of community museums become an "investment project" rather than a "cultural project"?

Therefore, we think the main theme of community museums is no longer to focus on a simple humanoriented concept, but more importantly, to present "cultural processes." In other words, we want to create a cultural brand unique to local residents, deconstructing Eurocentrism in the third world through these methods, so that they can find their own history and a warm future in this post-industrial society lacking human care.

\section{CONCLUSION}

In summary, the essay is about the history after the Second World War, and postcolonialism and Subaltern Studies are the basic theories about the Eurocentric idea of history. Based on these historical problems, we narrow down the research to the field of museology and the different situation of the development of museums in different regions. We hope to utilize the relevant ideas of New Museology to eliminate the dominant position of Eurocentric ideas of history, thus reshaping the conception of history in the post-colonial regions.

In addition, with the rapid development of archaeology, we also hope to build a bridge of communication and understanding among audiences, scholars, and government agencies by developing public archaeology. In this way, when the public visits community museums, they can change their selfjudgment on the authenticity of certain things and regain their recognition and affirmation of the exhibition history.

The essay not only deepens our understanding of these concepts but also helps us understand its future tendency. By analyzing the specific situations in different regions, we estimate to what extent new museums can virtually achieve this goal, thus reminding these museums to improve themselves based on the respective situation.
There are several limitations in this essay. Firstly, the analysis may be incomplete, and there is not enough reality to consider these problems. Secondly, due to limited information, we are unable to read all the literature on this issue. Finally, because of the time problem, we cannot make a more in-depth analysis. Therefore, our future research will continue to collect the cases of the third world countries, analyze the cases according to the unique historical background and social background, and discuss how to obtain the operating funds of ecological museums and community museums established for this purpose through analysis.

\section{REFERENCES}

[1] John Holloway. (2009). Negativity and Revolution: Adorno and Political Activism. Pluto Press.

[2] Mary Bouquet. (2012). Museum. A Visual Anthropology. Berg Publisher.

[3] David Carrier. (2007). Museum Skepticism. A History of the Display of Art in Public Galleries. Duke University Press.

[4] Liu Shifeng and Gan Daijun. (2011). An Analysis of the Social Thought Roots of the Eco-museum Movemen. "Southeast Culture" Magazine.

[5] Zheng Bangyan. (2014). How Difficult Is It to Expose the Hidden Pain? A review of the Knowledge of the Exhibition: The Violence in Public Space in the Past. Chinese Taiwan: Museum and Culture, No.7, 2014

[6] Yin Kai. (2016). Imagination of Utopia: Multiculturalism and Eco-museum Ideas. Chinese museum, No.4, 2016

[7] Liu Fan. (2016). From the Perspective of Others to Diversified Identities_-Research on Museum Exhibition Planning from the Perspective of Anthropology. http://dxdo.org/10.21004 /issn.1003 -840x.2016.05.194

[8] Cui Tianxing. (2014). On the Concept of "Community Archaeology". China Heritage Journal.

[9] Yi Kai. (2016). Utopian imagination: multiculturalism and the thought of ecological museums, Chinese Museum.

[10] Nick Taylor, Keith Cheverst. (2012). Supporting Community Awareness with Interactive Displays. IEEE Computer 2012, 45(5), 26-32.

[11] Pan Shouyong. (2017). The Eco-museum (Community Museum): Chinese Experiences and Critical Discussions. "Southeast Culture" Magazine. 
[12] The State Administration of Cultural Heritage of China. The Notice Regarding to the Development of Eco-museum (Community Museum). (2011), http://www.gov.cn/zwgk/201108/23/content_1930809.htm.

[13] Garcia, J. (2003). Latino politics in America: Community, culture, and interests. Lahman, MD: Rowman and Littlefield.

[14] Pan Shouyong. (2017). The Chinese Experience and Academic Critical Reflection of Community Museums [J]. Southeastern Culture, 2017(06): 115121,127-128.

[15] Bowden Will. (2021). What is the role of the academic in community archaeology? The changing nature of volunteer participation at Caistor Roman town [J]. Journal of Community Archaeology \& Heritage, 2021, 8(2).

[16] Zhang Li. (2020). The Development of Cultural and Creative Industries of Museums in the New Era: Experience and Enlightenment [J]. Journal of Southwest University for Nationalities (Humanities and Social Sciences Edition), 2020, 41(02): 200205.

[17] Zhou Jingjing. (2021). Re-understanding of the museum's "audience-centered" concept $[\mathrm{J}]$. Chinese Museum, 2021(01): 28-36,127. 